\title{
Prevalence and Antimicrobial Resistance Profiles of Bacterial Isolates Associated with Intramammary Infections in Malaysian Dairy Herds
}

\section{Bashir A.}

Universiti Putra Malaysia

Zunita Z. ( $\square$ zunita@upm.edu.my )

Universiti Putra Malaysia https://orcid.org/0000-0003-1792-6128

Jesse F.F.

Universiti Putra Malaysia

Ramanoon S.Z.

Universiti Putra Malaysia

Mohd-Azmi M.L.

Universiti Putra Malaysia

Research article

Keywords: Antimicrobial Resistance, Bacteria, Mastitis, Malaysia, Prevalence

Posted Date: July 27th, 2020

DOl: https://doi.org/10.21203/rs.3.rs-41383/v1

License: (9) This work is licensed under a Creative Commons Attribution 4.0 International License.

Read Full License 


\section{Abstract \\ Background}

Intramammary Infections are costly endemic diseases in dairy cows and it highly affect both the quality and quantity of milk production in addition to the animal wellbeing. It a major cause of considerable economic losses to the dairy farmers. This study was aimed to determine the prevalence of mastitis pathogens and antimicrobial resistance pattern of selected most prevalent pathogens.

\section{Results}

The overall culture prevalence was $67.6 \%(n=503 / 744, \mathrm{Cl}=64.1-70.9)$. The respective states' culture prevalence was $66.4 \%(n=71 / 107, \mathrm{Cl}=56.5-75.0), 60.3 \%(184 / 305, \mathrm{Cl}=54.6-65.8), 58 \%(\mathrm{n}=94 / 162, \mathrm{Cl}$ $=50-65.6), 100 \%(n=75 / 75, \mathrm{Cl}=93.9-100)$, and 83.3\% ( $=79 / 95, \mathrm{Cl}=73.8-89.8)$ for Pahang, Perak, Selangor, Negeri Sembilan and Johor respectively. The most prevalent isolates identified were non-aureus staphylococci (NAS) $39.5 \%$, S. aureus $13.1 \%$, K. pneumoniae $6.5 \%$, S. agalactiae $4.8 \%$, and S. uberis $4.3 \%$. Resistance profile of Actinobacter spp against chloramphenicol and streptomycin were $71.4 \%$ and $35.7 \%$ respectively. For $S$. uberis isolates, $66.7 \%$ and $73.3 \%$ have shown resistance to tetracycline and streptomycin respectively.

\section{Conclusions}

This study provides knowledge of the epidemiology of bacterial isolates associated with subclinical mastitis in Malaysia and their resistance profile. The high prevalence of these pathogens in milk and multidrug resistance observed should not be over looked.

\section{Background}

Because of the world's growing population, there is need to increase the amount of food production to meet its demand (Klaas \& Zadoks, 2018). Dairy products including milk are important food source for many people globally, with over 6 billion people taking dairy milk on daily basis. In addition, dairying is significant source of livelihoods to over 1 billion farmers around the world especially rural dwellers (FAO, 2016).

Bovine mastitis, which is the intramammary infection (IMI) of the dairy cows is a major constraint to milk production especially in the developing countries (Abrahmsén et al., 2014). It is therefore important to investigate the epidemiology of this disease especially in small-scale farmer herds in order to establish its real causal agents.

More than 135 types of microbes were reported to be previously implicated in bovine mastitis cases, but the most associated were staphylococci, streptococci, and Gram negative bacteria (Bradley, 2002). The 
composition of many strains of bacteria associated with mastitis has changed with time. The prevalence of contagious pathogens especially $S$. agalactiae has drastically reduced due to some mastitis control measures like improved milking system (Makovec and Ruegg, 2003; Pitkälä et al., 2010).

Antimicrobial therapy forms an important part of mastitis management and control. However, even with the best possible treatment regimens, it is common to experience failures in bacteriological cure and one of the main reasons is associated with antimicrobial resistance (Saini et al., 2012). Mastitis results in an increased use of antibiotics in dairy herds, and resistance of mastitis agents to antibiotics is a wellknown problem in dairy animals (Tenhagen, et al. 2006). The world health organization (WHO) has warned that the use of any antimicrobial agent is related to the risk causing resistance to antimicrobials in bacteria (WHO, 1997). This necessitates the need for more studies on the use of antimicrobials in food producing animals and the assessment of potential risk factors that influence the magnitude of antimicrobial resistance among mastitis pathogens (Tenhagen, et al. 2006).

Mastitis pathogens in Malaysia and their antimicrobial susceptibility profiles have been previously reported (Othman \& Bahaman, 2005; Murugaiyah et al., 2014; Ahmed et al., 2016). However, these studies involved small number of farms in a region or state. As such, very little is known about the current epidemiology of mastitis pathogens in Peninsular Malaysia. Additionally, depending on the climatic conditions, animal species, and animal husbandry practices, aetiological agents of mastitis.

\section{Methods}

\section{Study design and sample size}

This is a cross-sectional study carried out in five selected states of Peninsular Malaysia, comprising of Selangor, Negeri Sembilan, Johor, Pahang and Perak (Figure 1) from 2015 to 2018.

A sample size of 384 cows was determined using a formula (Thrustfield, 2005) based on 95\% confidence level, $5 \%$ margin of error, and expected prevalence of mastitis at cow level of $50 \%$. However, to achieve better representation of all the various districts across the five states under study, 517 dairy cows from 33 dairy herds were used.

In essence, 744 California mastitis test (CMT) positive samples screened from 1945 total quarter samples were used in this study. The herds were selected from the list provided by the individual state Department of Veterinary Services (DVS). The herd selection was based on the number of lactating dairy cattle in each farm (at least 10 milking cows) and based on farm accessibility granted by the farmers. The number of cows sampled were proportionate to the total number of cows in each individual herd. All farms were visited once from 2015 to 2018.

\section{Sample collection}

Milk samples collection was done adopting technique previously discussed by Oliver (2004). Teats were cleaned and dried with towel. Then it was sterilized vigorously with moistened cotton soaked in $70 \%$ 
ethanol. The udder sanitization was done in a way to avoid recontamination. Therefore, far teats were first sanitized followed by the nearby ones. Some streams of milk from each teat were discarded first before collecting about $10 \mathrm{ml}$ of the milk samples from each teat into a separate well labelled screw caped sample bottle. Samples were immediately kept in ice box and transported to the lab for further analyses.

\section{Isolation and identification of bacterial pathogens}

Isolation of bacterial pathogens was carried out as described by Abebe et al., (2016). A loop of milk sample was taken and then streaked on both blood and MacConkey agar (Oxoid, UK) plates in both directions. For samples that were kept in chiller, they were incubated at $25^{\circ} \mathrm{C}$ for 15 minutes in order to disperse the bacteria that might be concentrated in the cream layer or held by clumps of fat globules before then inoculated on the agar plates. Plates were then incubated aerobically at $37^{\circ} \mathrm{C}$ for 24 hours. All plates were examined for bacterial growth, and other physical characteristics. Colonies of interest were picked for subculture on blood agar. Streaking was done by dilution quadrant method to obtain pure colonies. Afterwards, gram- staining was conducted to identify the colonies as gram positive or gramnegative, catalase and coagulase test were conducted. Identification of the isolates were accomplished using analytical profile index (API) kits (Biomerieux ${ }^{\circledR}$, France) following manufacturer's guidelines.

\section{Antimicrobial sensitivity testing}

Antibiotic sensitivity testing of selected most prevalent pathogens obtained from bacterial culture was conducted by Kirby- Bauer disk diffusion technique as described by Suleiman et al., (2017). All isolates were cultured on blood agar plates (Oxoid, UK). Few colonies from the blood culture were suspended into $2 \mathrm{ml}$ of Brain Heart Infusion (BHI) broth (Oxoid, UK). The tubes were incubated for $2-6$ hours at $37^{\circ} \mathrm{C}$. Toward the end of the incubation period, prepared Mueller Hinton agar (Oxoid, UK) were dried. Sterile swabs were used to inoculate the organisms from the $2 \mathrm{ml} \mathrm{BHI}$ broth which have been adjusted to 0.5 McFarland standard onto the surface of the MHA. Antibiotic discs (Oxoid, UK) impregnated with standard concentrations of antibiotics were placed using disc dispenser and sterile forceps to firmly stick to the agar surface. Plates were incubated at $37^{\circ} \mathrm{C}$ for 24 hours after which zones of inhibitions were measured using Vernier Caliper. Test organisms were labelled as sensitive and resistant, intermediate label were also considered as resistant. A total of twelve $(n=12)$ antibiotics commonly used in veterinary practice were used against a total of two hundred and seven $(n=207)$ bacterial pathogens. The antibiotics used were Chloramphenicol, Gentamicin, Tetracycline, Sulphamethoxazole-trimethoprim, Ampicillin, Ceptiofur, Azithromycin, Penicillin and Streptomycin. The bacterial pathogens tested were $S$. aureus $(\mathrm{n}=54)$, NAS ( $=53)$, Actinobacterspp $(\mathrm{n}=28)$, K. pneumoniae $(\mathrm{n}=27)$, E. coli $(\mathrm{n}=19)$, S. uberis $(\mathrm{n}=15)$ and Enterobacterspp $(\mathrm{n}=11)$. E. coli ATCC 25922 and S. aureus ATCC 29213 were used as controls for Grampositive and Gram-negative isolates respectively. The break point of resistance for all isolates against the antibiotics tested adopted from EUCAST and CLSI is shown in Table 1. 
Table 1

Potency and resistant break points for antibiotics used against selected pathogens.

\begin{tabular}{|lll|}
\hline Antibiotics & Resistant break points & Disk potency $(\mu \mathrm{g})$ \\
\hline Chloramphenicol & $\leq 17$ & 50 \\
\hline Gentamicin & $\leq 17$ for Enterobacterales* & 10 \\
& $\leq 18$ for others & \\
\hline Tetracycline & $\leq 19$ for Enterobacterales* & 30 \\
& $\leq 20$ for others \\
\hline Sulphamethoxazole-trimethoprim & $\leq 15$ for S. aureus & \\
& $\leq$ for S. uberis & \\
& $\leq 11$ for Enterobacterales* & \\
\hline Ampicillin & $\leq 14$ & 10 \\
\hline Ceftiofur & - & 30 \\
\hline Azithromycin & & 15 \\
\hline Penicillin G & $\leq 15$ for others & 10 \\
\hline Streptomycin & $\leq 29$ for Staphylococci & 5 \\
\hline *The enterobacterales involved in the study were E. coli, Actinobacter sp., K. pneumonia and \\
Enterobacter sp. & $\leq 15$ & \\
\hline
\end{tabular}

\section{Results}

\section{Isolation and identification of bacterial pathogens Culture prevalence of IMls}

The overall culture prevalence based on bacterial culture was recorded as $67.6 \%(503 / 744,95 \% \mathrm{Cl}=64.1-$ 70.9). Ten (10) culture plates were found to be contaminated and were excluded, this is because more than two different bacterial isolates were found. The states' prevalence ranges from $58-100 \%$, with Selangor and Negeri Sembilan having the lowest and highest respectively. Statistical difference was observed on the culture prevalence between the states $(\chi 2=10.6, P=0.03)$. These results are shown in Table 2. 
Table 2

The overall and individual states' culture prevalence of IMIs

\begin{tabular}{|c|c|c|c|c|c|c|}
\hline States & $\begin{array}{l}\text { Number of } \\
\text { samples } \\
\text { collected }\end{array}$ & $\begin{array}{l}\text { Number of } \\
\text { culture positive } \\
\text { samples }\end{array}$ & $\begin{array}{l}\text { Number of } \\
\text { contaminated } \\
\text { samples }\end{array}$ & $\begin{array}{l}\text { Culture } \\
\text { Prevalence } \\
\text { (\%) }\end{array}$ & $\begin{array}{l}95 \% \\
\mathrm{Cl}\end{array}$ & $x^{2}$ \\
\hline Pahang & 107 & 71 & 2 & 66.4 & $\begin{array}{l}56.5- \\
75.0\end{array}$ & 10.6 \\
\hline Perak & 305 & 184 & 4 & 60.3 & $\begin{array}{l}54.6- \\
65.8\end{array}$ & $\begin{array}{l}\mathrm{P}= \\
0.032\end{array}$ \\
\hline Selangor & 162 & 94 & 1 & 58.0 & $\begin{array}{l}50- \\
65.6\end{array}$ & \\
\hline $\begin{array}{l}\text { Negeri } \\
\text { Sambilan }\end{array}$ & 75 & 75 & - & 100 & $\begin{array}{l}93.9- \\
100\end{array}$ & \\
\hline Johor & 95 & 79 & 3 & 83.2 & $\begin{array}{l}73.8- \\
89.8\end{array}$ & \\
\hline Total & 744 & 503 & 10 & 67.6 & $\begin{array}{l}64.1- \\
70.9\end{array}$ & \\
\hline
\end{tabular}

\section{Distribution of bacterial pathogens}

The distribution of the overall bacterial pathogens associated with subclinical mastitis from five states are shown in Fig. 2. The group of bacteria that constitutes the major part of isolates associated with subclinical mastitis were the non-aureus staphylococci (NAS), with a total prevalence of $39.5 \%(232 / 588$, $95 \% \mathrm{Cl}=35.5-43.6)$. This is followed by $S$. aureus as second most prevalent which constitutes $13.1 \%$ $(77 / 588,95 \% \mathrm{Cl}=10.5-16.2)$ and then $K$. pneumoniae in third position with prevalence of $6.5 \%(38 / 588$, $95 \% \mathrm{Cl}=4.6-8.8)$. The next most prevalent bacterial pathogens identified were Streptococcus agalactiae $4.8 \%(25 / 588,95 \% \mathrm{Cl}=2.8-6.3)$, Streptococcus uberis $4.3 \%(25 / 588,95 \% \mathrm{Cl}=2.8-6.3)$, Enterobacter cloacae $3.6 \%(21 / 588,95 \% \mathrm{Cl}=2.3-5.5)$ and Escherichia coli $3.2 \%(19 / 588,95 \% \mathrm{Cl}=2.0-5.1)$. The rest were Yeast 2.7\% $(16 / 588,95 \% \mathrm{Cl}=1.6-4.5)$, other environmental Streptococci $2.7 \%(16 / 588,95 \% \mathrm{Cl}=1.6-$ 4.5), Corynebacterium spp $2.2 \%(13 / 588,95 \% \mathrm{Cl}=1.2-3.8)$, Micrococcus spp $2.2 \%(13 / 588,95 \% \mathrm{Cl}=1.2-$ 3.8), Pantoea spp $2.0 \%(12 / 588,95 \% \mathrm{Cl}=1.1-3.6)$, S. dysagalactiae $1.9 \%(11 / 588,95 \% \mathrm{Cl}=0.9-3.4)$, others $6.0 \%(35 / 588,95 \% \mathrm{Cl}=4.2-8.2)$ and $5.4 \%(32 / 588,95 \% \mathrm{Cl}=3.8-7.6)$ as unidentified.

The distribution of agents associated with IMls vary among the states. In Selangor (Fig. 3), yeasts (13.1\%) were found to be the most prevalent agents followed by Staphylococcus scuiri $(11.1 \%)$ and then Staphylococcus intermedius (10.1\%). In Negeri Sembilan (Fig. 4), S. haemolyticus (12.2\%) is the most prevalent isolate followed by S. hominis (10.4\%) and S. Iugdunensis (8.7\%). In Johor (Fig. 5), S. aureus $(37.4 \%)$ is the most prevalent followed by S. xylosus (15.4\%) and then S. lentus (6.6\%). In Perak (Fig. 6), S. 
aureus (15.3\%) is the most prevalent followed by K. pneumoniae(14.4\%) and S. agalactiae (9.4\%). In Pahang (Fig. 7), S. xylosus (18.6\%) is the most prevalent followed by E. coli (15.1\%) and then S. lentus (10.5\%).

The non-aureus staphylococci which was shown to be the most prevalent group of pathogens associated with subclinical mastitis, were further broken to specie level and compared with $S$. aureus isolates to have better understanding of their composition and distribution as shown in Fig. 8.

\section{Antimicrobial resistance profile}

The antimicrobial resistance profile of the isolates tested is shown in Table 3.3. The resistance levels of the antimicrobials vary among the mastitis isolates tested. For the overall isolates, the highest resistance levels observed were 25.6\% for Streptomycin, 22.2\% for Penicillin G, 21.3\% for Tetracycline and 20.3\% for Ampicillin. This is followed by $16.4 \%$ for Cefotaxime, $14.5 \%$ for Chloramphenicol, $13 \%$ for Azithromycin, $12.1 \%$ for Sulphamethoxazole-trimethoprim. The least resistance levels were observed for Gentamicin and Ceftiofur with $6.3 \%$ and $3.9 \%$ respectively. For individual isolates, relatively low levels of resistance were demonstrated against the tested antibiotics. However, some isolates have shown quite high level of resistance against few antibiotics. It can be observed that resistance profile of $K$. pneumoniae isolates against ampicillin and Penicillin G were $70.4 \%$ and $88.9 \%$ respectively while that of Actinobacter spp against chloramphenicol and streptomycin were $71.4 \%$ and $35.7 \%$ respectively. For $S$. uberis isolates, $66.7 \%$ and $73.3 \%$ have shown resistance to tetracycline and streptomycin respectively.

Table 3. The resistance profile of major pathogens implicated in subclinical mastitis from dairy herds in Malaysia against some commonly used antibiotics in veterinary practice

\begin{tabular}{lcccccccccc}
\hline Isolates & \multicolumn{8}{c}{ Number of isolates resistant against the tested antibiotics (\%) } \\
\cline { 2 - 10 } & $\mathrm{C}$ & $\mathrm{CN}$ & $\mathrm{TE}$ & $\mathrm{SXT}$ & AMP & EFT & AZT & P & S & CXT \\
\hline NAS & $1(1.9)$ & $1(1.9)$ & $9(16.9)$ & $6(11.3)$ & $1(1.9)$ & $1(1.9$ & $6(11.3)$ & $3(5.6)$ & $21(39.6)$ & $3(5.6)$ \\
S. aureus & $2(3.7)$ & $4(7.4)$ & $12(22.2)$ & $5(9.3)$ & $5(9.3)$ & $0(0)$ & $7(13.0)$ & $4(7.4)$ & $8(14.8)$ & $16(29.6)$ \\
Actinobacter spp & $20(71.4)$ & $0(0)$ & $4(14.3)$ & $1(3.5)$ & $4(14.3)$ & $0(0)$ & $0(0)$ & $7(25)$ & $10(35.7)$ & $4(14.3)$ \\
Klebsiella pneumoniae & $2(7.4)$ & $0(0)$ & $5(18.5)$ & $4(14.8)$ & $19(70.4)$ & $0(0)$ & $5(18.5)$ & $24(88.8)$ & $2(7.4)$ & $2(7.4)$ \\
E. coli & $0(0)$ & $0(0)$ & $4(21.1)$ & $2(10.5)$ & $0(0)$ & $0(0)$ & $1(5.3)$ & $1(5.3)$ & $0(0)$ & $2(10.5)$ \\
S. uberis & $1(6.6)$ & $8(53.3)$ & $10(66.6)$ & $7(46.6)$ & $7(46.6)$ & $7(46.6)$ & $4(26.7)$ & $7(46.7)$ & $11(73.3)$ & $7(46.7)$ \\
Enterobacter spp & $0(0)$ & $0(0)$ & $0(0)$ & $0(0)$ & $6(54.5)$ & $0(0)$ & $5(45.5)$ & $0(0)$ & $1(9.1)$ & $0(0)$ \\
Total & $\mathbf{3 0 ( 1 4 . 5 )}$ & $\mathbf{1 3 ( 6 . 3 )}$ & $\mathbf{4 4 ( 2 1 . 3 )}$ & $\mathbf{2 5 ( 1 2 . 1 )}$ & $\mathbf{4 2 ( 2 0 . 3 )}$ & $\mathbf{8 ( 3 . 9 )}$ & $\mathbf{2 7 ( 1 3 . 0 )}$ & $\mathbf{4 6 ( 2 2 . 2 )}$ & $\mathbf{5 3 ( 2 5 . 6 )}$ & $34(\mathbf{1 6 . 4 )}$ \\
\hline
\end{tabular}

$\mathrm{C}=$ Chloramphenicol C $(50 \mu \mathrm{g}), \mathrm{CN}=$ Gentamicin $(10 \mu \mathrm{g}), \mathrm{TE}=$ tetracycline $(30 \mu \mathrm{g}), \mathrm{SXT}=$ Sulphamethoxazole-trimethoprim $(25 \mu \mathrm{g}), \mathrm{AMP}=\mathrm{Ampicillin}$ $(10 \mu \mathrm{g}), \mathrm{ETF}=\mathrm{Ceftiofur}(30 \mu), \mathrm{AZT}=$ Azithromycin $(15 \mu \mathrm{g}), \mathrm{P}=$ Penicillin G $(10 \mu \mathrm{g}), \mathrm{S}=$ Streptomycin $(25 \mu \mathrm{g}), \mathrm{CXT}=\mathrm{Cefotaxime}(5 \mu \mathrm{g})$

\section{Discussion}

The prevalence of mastitis based on bacteriological culture in this study is recorded as $67.6 \%$. Local comparison of this result with other findings was a bit difficult due to either difference in study design or 
sample size. Both studies previously conducted by Othman and Bahaman (2005) and Murugaiyah et al. (2014), that relate to findings on bacterial pathogens associated with mastitis in Malaysia have not clearly stated the overall culture prevalence recorded, although a significant number of bacterial pathogens associated with mastitis were isolated. In another study involving the bacteriological quality and safety of raw milk from milk collection centers in Peninsular Malaysia, conducted by Chye et al. (2004), only reported the distribution of bacterial isolates observed. Similarly, a study conducted by Ahamed et al. (2016) focused only on isolation of $S$. aureus from 60 raw milk samples obtained from small scale farmers in Penang with a culture prevalence of $100 \%$. This prevalence is higher as compared to present study although the study design is entirely different. However, in a smaller but related study conducted by Ching et al. (2011), the culture prevalence recorded was $91 \%$, which is higher than the present study. To date, to the best of our knowledge, this is the most comprehensive study conducted in Malaysia.

Based on states, the prevalence of subclinical mastitis recorded were significantly different (P-value $=$ $0.032)$. Negeri Sembilan has the highest prevalence $(100 \%)$ followed by Johor $(83.2 \%)$. The third is Pahang $(66.4 \%)$, fourth is Perak $(60.3 \%)$ and Selangor has the least with $58 \%$. The high prevalence levels recorded in the states is an indication of the how much losses have been incurred due to reduction in milk quality and quantity, as well as cost of veterinary services due to subclinical mastitis in these regions (Mushtaq et al., 2018b).

Studies conducted in Ethiopia by Birhanu et al. (2017) reported a culture prevalence of $90 \%, 33.5 \%$ in Finland (Pitkälä et al., 2004), 42.9\% in Tanzania (Suleiman et al., 2017), 26.4\% in Germany (Tenhagen et al., 2006), 84.2\% in China (Gao et al., 2017) and 86.2\% in Uganda (Abrahmsén et al., 2014). The prevalence of subclinical mastitis recorded in the present study and the variation in other studies could be due to many factors ranging from the farm management practices, the animal's factors, the pathogen factors and the environmental factors (Birhanu et al., 2017).

The NAS and $S$. aureus were the most predominant pathogens isolated in this study. Non-aureus staphylococci (NAS) are diverse set of about 50 bacterial species of which 20 are commonly associated with subclinical mastitis (Nyman et al., 2018). This study is in conformity with many studies where the trend shows the dominance of NAS group of bacteria in association with subclinical mastitis. NAS has been identified as the most common pathogens associated with subclinical mastitis in countries like Finland, Netherlands, Germany, and South Africa (Pitkälä et al., 2004; Tenhagen et al., 2006; Petzeret al., 2009; Sampimon et al., 2009). These group of bacteria are often found on teat apices of lactating dairy cows and it has been suggested that the colonization of the teat apex may serves as reservoir for NAS species causing IMIs (Traversari et al., 2019).

Staphylococcus aureus is the predominant of all the staphylococcal species (S. aureus and NAS) isolated in this study. Similar results have been reported previously from Malaysia, although the prevalence among these studies varies (Othman and Bahaman, 2005; Murugaiyah et al., 2014; Ahamed et al., 2016). High prevalence trend of $S$. aureus in association of subclinical mastitis has been reported elsewhere in 
France, China, and Ethiopia (Birhanu et al., 2017; Poutrel et al., 2018; Wang et al., 2018). Is one of the main pathogens for contagious mastitis, and it is believed to be transmitted during milking (Anderson et al., 2012). Lack of dry cow therapy in dairy herds could be responsible for continuous transmission of contagious pathogens like $S$. aureus and $S$. agalactiae. These pathogens are mostly found in teat canals, on teat or udder skin and are the common source of infection between infected and uninfected cows (Birhanu et al., 2017). In most cases, one or more prevalent strains of $S$. aureus may affect multiple cows (Middleton et al., 2002a; Zadoks et al., 2000). The common way by which $S$. aureus is transmitted to uninfected quarters is via teat cup liners, hand of milkers, and wash cloths. However, heifers are commonly infected during the first calving, even though are not in contact with milking machine or exposed to milking procedure, which was thought to the source of S. aureus. In which case, colonised flies were fingered to be possible vectors for the transmission of $S$. aureus (Anderson et al., 2012; Owens et al., 1998). Transmission of infection may occur from one teat to another by the claw piece (Nyhan and Cowhing, 1967). Contamination of the teats could be as a result of vacuum fluctuations which can cause a condition such as reverse flow, reverse spray and jet flow (Hamann, 2010).

Klebsiella pneumoniae constitutes $6.5 \%$ of the isolates recovered in this study. Klebsiella pneumoniae has been recognized as one of the agents of clinical mastitis of environmental origin (Zadoks et al., 2011). Mastitis due to K. pneumoniae is associated with reduction of milk production in dairy cows even after recovery (Podder et al., 2014).

Other important mastitis pathogens found in the study were S. agalactiae and S. uberis. Streptococcus agalactiae is a common contagious mastitis agent that is found on cow's gland and mostly transmitted at milking (NMC, 1999). Though infection with S. agalactiae shows little or no signs, it is however associated with low milk production and increased SCC (Barkema et al., 2009). On the other hand, Streptococcus uberis has been shown to induce mastitis (Phuektes et al., 2001). However, the epidemiology of this bacterium is not well understood. This is because it has been recovered in a number of sites such as skin surface, genital tract, intestinal tract, and tonsils (Cullen \& Little, 1969; Sharma \& Packer, 1970). It has also been reported that $S$. uberis mastitis was in associated with the bedding, which is regarded as a major source of IMls (Phuektes et al., 2001).

The findings from this study also indicates that environment may serve as source of infection (Oliveira and Ruegg, 2014) with the recovery of E. coli as one of the identified isolate. Escherichia coli is classified as common opportunistic environmental pathogen, known to cause intramammary infection in dairy cows (Zadoks et al., 2011). It is commonly associated with clinical mastitis, and its severity may range from mild to fatal and mostly attributed to host-characteristics or factors such as age, lactation stage and breed (Burvenich et al., 2003).

Enterobacterspp has been reported from previous studies (Sumon et al., 2017) and are important agents of environmental intramammary infection and are mostly sourced from farm manure, bedding, and soil (Swartz and Christina, 2016). 
The distribution and composition of isolates associated with subclinical mastitis based on states varies (Figs. 3-7). Bovine mastitis due to yeasts especially Candida spp has been reported elsewhere (Du et al., 2018). IMls caused by yeasts are linked to treatment against other IMI pathogens, cross infection from contaminated syringes and cannulas and or contaminated antibiotic preparations (Dworecka-Kaszak et al., 2012). In Negeri Sembilan, the most prevalent species isolated were S. aureus (7.9\%), Streptococcus uberis (7.9\%), and Enterobacterspp (5.3\%). In Johor, the predominant species were S. aureus (37.4\%), S. xylosus (15.4\%), S. lentus (6.6\%) and S. intermedius (5.5\%). In Pahang, the most prevalent species were $S$. xylosus (19.0\%), E. coli (15.5\%), S. lentus (10.7\%) and K. pneumoniae (8.3\%). In Perak, the most prevalent bacterial species associated with subclinical mastitis were $S$. aureus (15.3\%), K. pneumoniae (14.4\%), $S$. agalactiae (9.4\%) and $S$. intermedius (6.4\%). This agrees with results from previous findings (Othman and Bahaman, 2005; Ching et al., 2011; Murugaiyah et al., 2014).

The difference in the composition and distribution of pathogens causing IMls among the states may be associated with farm management practices such as dipping, dry cow therapy, hygiene nature of the farm, housing type (Abebe et al., 2016) as well as cow's and pathogens factors (Klass and Zadoks, 2017).

Antibiotic susceptibility testing was carried out on selected most prevalent pathogens associated with bovine mastitis isolates from the studied farms. Isolates were selected based on prevalence, and they were tested against most commonly used antibiotics in veterinary practices. The selected pathogens were NAS, S. aureus, E. coli, K. pneumoniae, S. uberis, Actinobacterspp and Enterobacter spp.

Overall, low resistance profile was observed on the isolates against the tested antibiotics. The NAS and $S$. aureus isolates have shown good in-vitro response to a larger extent to the tested antimicrobials. This may be due to little spread of emerging antimicrobial drug resistance among mastitis pathogens as suggested by National Council's Group of Expert (Erskine et al. 2004). However, in the case of few pathogens like $K$. pneumoniae, Actinobacter spp, and $S$. uberis, resistance against some antibiotics was observed.

For K. pneumoniae, $70.4 \%$ have shown resistance to Ampicillin, this is higher than $15.7 \%$ as previously reported (Erskine et al., 2002), but lower than 100\% reported by Othman \& Bahaman (2005). High resistance level (88.9\%) of K. pneumoniae against Penicillin $\mathrm{G}$ was also observed. This is in conformity with high level of resistance (100\%) of this bacterium to Penicillin by Suleiman et al., (2017). The high prevalence of resistance to Penicillin antibiotics recorded is quite alarming, and could be due to production of extended-spectrum beta-lactamase production by this bacterium (Ferreira et al., 2019).

In case of Actinobacterspp, $71.4 \%$ were resistant to Chloramphenicol and 50\% were resistant to Streptomycin. Similar levels of resistance of Actinobacter spp against these antibiotics have been reported (Nam et al., 2009). Studies have shown that Actinobacter spp are intrinsically resistant to antibiotics especially Cephalosporins, and possess remarkable ability to acquire resistance determinants to many antimicrobials (Perilli et al., 1996). Thus, the presence of multi-resistant Actinobacterspp can be a matter of public health concern. 
As for S. uberis, $66.7 \%$ and $73.3 \%$ were resistant to Tetracycline and Streptomycin respectively. The $66.7 \%$ resistance level of tetracycline is slightly higher than $57.6 \%$ previously reported by Nam et al. (2009). Resistance to tetracycline could be associated to common use of this antibiotic as an additives to livestock feeds, due to its ability to stimulate weight gains in some domestic animals (Speer et al., 1992) and possible abuse of this antibiotic during mastitis treatment (Siljanoski et al., 2018). Because of this, regular use of tetracycline in animal feeds should be regulated. Many genes that can confer streptomycin resistance have been identified on the plasmid. Among them are the $s t r A$ and $s t r B$, and are widely distributed in bacteria circulating in humans and animals (Pezzella et al., 2004).

\section{Conclusions}

The overall culture-based extensiveness as well as the composition and distribution of various bovine mastitis pathogens implicated in subclinical mastitis involving 33 herds originated from five states of Peninsular Malaysia have been established. The NAS and $S$. aureus were identified as the most prevalent pathogens associated with IMIs in this study. The high prevalence of IMIs recorded in this study is an indicator of the huge economic losses suffered by the dairy farmers involved. The knowledge of the pathogens associated with IMIs and their resistance profile would help in designing proper mastitis control programmes and effective therapy, thus improving the economy of the farmers.

\section{Abbreviation}

AMR Antimicrobial Resistance

API Analytical Profile Index

BHI Brain Heart Infusion

$\mathrm{Cl}$ Confidence Interval

CMT California mastitis test

DVS Department of veterinary services

FAO Food and Agriculture Organization

IMls Intramammary Infections

ml Milliliter

NAS Non-aureus Staphylococci

NMC National Mastitis Council 
OECD-FAO Organisation for Economic Co-operation and Development and the Food and Agriculture Organization of the United Nations

SCC Somatic Cell Count

UK United Kingdom

UPM Universiti Putra Malaysia

USD United State Dollar

WHO World Health Organization

\section{Declarations}

\section{Ethics approval and consent to participate}

This category of this research is excluded from the category that requires approval of the university's animal care and use committee, as it does not involve any invasive procedure on the animals and all milk samples were collected during the routine milking processes. However, consent approval was obtained from all the farmers involved through liaison with both the federal and state departments of veterinary services (DVS) prior to the conduct of this research.

\section{Consent to publish}

Not applicable

\section{Availability of data and materials}

Raw data not deposited. However, all raw data can be accessed via the corresponding author.

\section{Competing interest}

The authors declare that they have no competing interest.

\section{Funding}

This study was supported by the Universiti Putra Malaysia research grant number 9507600 . The university is reponsible for both the research conduct and publications related to it.

\section{Author's contribution}

AB plays role in data collection, analyses and drafting of the manuscript. ZZ plays role in project designing and supervision as well as reviewing of the manuscript. FFJ plays role in project designing and supervision as well as reviewing of the manuscript. SZR plays role in project designing and supervision 
as well as reviewing of the manuscript. M-LMA plays role in project designing and supervision as well as reviewing of the manuscript. All authors have read and approved the manuscript.

\section{Acknowledgement}

The authors thank the Division of Veterinary Services (DVS), Selangor, Malaysia for their assistance. Also we appreciate the farmers for their cooperation to participate in the study and all the technical staff of the Department of Medicine and Surgery of Farm and Exotic Animals, Faculty of Veterinary Medicine UPM Serdang Selangor, Malaysia.

\section{References}

Abebe, R., Hatiya, H., Abera, M., Megersa, B., \& Asmare, K. (2016). Bovine mastitis: Prevalence, risk factors and isolation of Staphylococcus aureus in dairy herds at Hawassa milk shed, South Ethiopia. BMC Veterinary Research, 12(1), 270.

Abrahmsén, M., Persson, Y., Kanyima, B. M., \& Båge, R. (2014). Prevalence of subclinical mastitis in dairy farms in urban and peri-urban areas of Kampala, Uganda. Tropical Animal Health and Production, 46(1), 99-105.

Ahamed Kamal Shamila-Syuhada, Gulam Rusul Wa Wan, NadiahWa Wan Nadiah, L. O. C. (2016). Prevalence and Antibiotics Resistance of Staphylococcus aureus Isolates Isolated from Raw Milk Obtained from Small-Scale Dairy Farms in Penang. Pakistan Veterinary Journal 98-102.

Barkema, H. W., Green, M. J., Bradley, A. J., \& Zadoks, R. N. (2009). Invited review: The role of contagious disease in udder health. Journal of Dairy Science, 92(10), 4717-4729.

Birhanu, M., Leta, S., Mamo, G., \& Tesfaye, S. (2017). Prevalence of bovine subclinical mastitis and isolation of its major causes in Bishoftu Town, Ethiopia. BMC Research Notes, 10(1).

Bradley, A. J. (2002a). Bovine Mastitis: An Evolving Disease. The Veterinary Journal, 164(2), 116-128.

Burvenich, C., Van Merris, V., Mehrzad, J., Diez-Fraile, A., \& Duchateau, L. (2003). Severity of E. coli mastitis is mainly determined by cow factors. Veterinary Research, 34(5):521-64.

Ching, K. L., Ramanoon, S. Z., \& Bejo, S. K. (2011). Mastitis in the Dairy Herd at Taman Pertanian Universiti Putra Malaysia. $6^{\text {th }}$ Proceedings of the Seminar on Veterinary Sciences. pp. 121.

Chye, F. Y., Abdullah, A., \& Ayob, M. K. (2004). Bacteriological quality and safety of raw milk in Malaysia. Food Microbiology, 21(5), 535-541.

Cullen, G. A., \& Little, T. W. (1969). Isolation of Streptococcus uberis from the rumen of cows and from soil. The Veterinary Record, 85(5), 115-118. 
Du, J., Wang, X., Luo, H., Wang, Y., Liu, X., \& Zhou, X. (2018). Epidemiological investigation of non-albicans Candida species recovered from mycotic mastitis of cows in Yinchuan, Ningxia of China. BMC Veterinary Research, 14(1), 251.

Erskine, R. J., Walker, R. D., Bolin, C. A., Bartlett, P. C., \& White, D. G. (2002). Trends in Antibacterial Susceptibility of Mastitis Pathogens During a Seven-Year Period. J. Dairy Sci 85(5), 1111-1118.

European Committee on Antimicrobial Susceptibility Testing. (2019). Breakpoint Tables for Interpretation of MICs and Zone Diameters, Version 9.0, http://www.eucast.org.

FAO. (2016). OECD-FAO Agricultural Outlook 2019-2028. Food and Agriculture Organization. OECD. https://doi.org/10.1787/agr_outlook-2019-en

Ferreira, R. L., Da Silva, B. C. M., Rezende, G. S., Nakamura-Silva, R., Pitondo-Silva, A., Campanini, E. B., Brito, M. C. A., Da Silva, E. M. L., Freire, C. C. D., Da Cunha, A. F., \& Da Silva Pranchevicius, M. C. (2019). High prevalence of multidrug-resistant klebsiella pneumoniae harboring several virulence and $\beta$ lactamase encoding genes in a brazilian intensive care unit. Frontiers in Microbiology, 9:3198.

Gao, J., Barkema, H. W., Zhang, L., Liu, G., Deng, Z., Cai, L., Shan, R., Zhang, S., Zou, J., Kastelic, P.J. \& Han, B. (2017). Incidence of clinical mastitis and distribution of pathogens on large Chinese dairy farms. Journal of Dairy Science, 100(6), 4797-4806.

Klaas, I. C., \& Zadoks, R. N. (2018). An update on environmental mastitis: Challenging perceptions. Transboundary and Emerging Diseases, 65, 166-185.

Makovec, J. A., \& Ruegg, P. L. (2003). Antimicrobial resistance of bacteria isolated from dairy cow milk samples submitted for bacterial culture: 8,905 Samples (1994-2001). Journal of the American Veterinary Medical Association, 222(11), 1582-1589.

Murugaiyah, M., Faez Firdaus, J. A., Konto, M., Poshpum, S. S., Lawan, A., Abdinasir Yusuf, O., Yusuf, A. \& Abdulnasir, T. (2014). Prevalence and antimicrobial resistance assessment of subclinical mastitis in milk samples from selected dairy farms. American Journal of Animal and Veterinary Sciences, 9(1), 65-70.

Mushtaq, S., Shah, A. M., Shah, A., Lone, S. A., Hussain, A., Hassan, Q. P., \& Ali, M. N. (2018a). Bovine mastitis: An appraisal of its alternative herbal cure. Microbial Pathogenesis. 114:357-61.

Nam, H.-M., Lim, S.-K., Kang, H.-M., Kim, J.-M., Moon, J.-S., Jang, K.-C., Kim, J. M., Joo, Y. S.Jung, S.-C. (2009). Antimicrobial Resistance of Streptococci Isolated from Mastitic Bovine Milk Samples in Korea. Journal of Veterinary Diagnostic Investigation, 21(5), 698-701.

Nam, H. M., Lim, S. K., Kang, H. M., Kim, J. M., Moon, J. S., Jang, K. C., Joo, Y. S., Kang, M. I., \& Jung, S. C. (2009). Prevalence and antimicrobial susceptibility of gram-negative bacteria isolated from bovine mastitis between 2003 and 2008 in Korea. Journal of Dairy Science, 92(5), 2020-2026. 
Nyman, A., Fasth, C., \& Waller, K. P. (2018). Intramammary infections with different non- aureus staphylococci in dairy cows. Journal of Dairy Science, 101(2), 1403-1418.

Oliver, S. P. (2004). Microbiological procedures for the diagnosis of bovine udder infection and determination of milk quality. Verona, Wis. pp.47.

Othman, N., \& Bahaman, A. (2005). Prevalence of Subclinical Mastitis And Antibiotic Resistant Bacteria In Three Selected Cattle Farms In Serdang, Selangorand Kluang. Journal of Veterinary Malaysia, 17(1), 2731.

Perilli, M., Felici, A., Oratore, A., Cornaglia, G., Bonfiglio, G., Rossolini, G. M., \& Amicosante, G. (1996). Characterization of the Chromosomal Cephalosporinases Produced by Acinetobacter Iwoffii and Acinetobacter baumannii Clinical Isolates. Antimicrobial Agents and Chemotherapy, 40(3), 715-719.

Petzer, I. M., Karzis, J., Watermeyer, J. C., Van der Schans, T. J., \& Van Reenen, R. (2009). Trends in udder health and emerging mastitogenic pathogens in South African dairy herds. Journal of the South African Veterinary Association, 80(1), 17-22.

Pezzella, C., Ricci, A., DiGiannatale, E., Luzzi, I., \& Carattoli, A. (2004). Tetracycline and Streptomycin Resistance Genes, Transposons, and Plasmids in Salmonella enterica Isolates from Animals in Italy. Antimicrobial Agents and Chemotherapy, 48(3), 903-908.

Phuektes, P., Mansell, P. D., Dyson, R. S., Hopper, N. D., Dick, J. S., \& Browning, G. F. (2001). Molecular epidemiology of Streptococcus uberis isolates from dairy cows with mastitis. Journal of Clinical Microbiology, 39(4), 1460-1466.

Pitkälä, A., Haveri, M., Pyörälä, S., Myllys, V., \& Honkanen-Buzalski, T. (2004a). Bovine Mastitis in Finland 2001-Prevalence, Distribution of Bacteria, and Antimicrobial Resistance. Journal of Dairy Science, 87(8), 2433-2441.

Pitkälä, A., Haveri, M., Pyörälä, S., Myllys, V., \& Honkanen-Buzalski, T. (2004b). Bovine mastitis in Finland 2001 - Prevalence, distribution of bacteria, and antimicrobial resistance. Journal of Dairy Science, 87(8), $2433-2441$.

Pitkälä, A., Haveri, M., Pyörälä, S., Myllys, V., \& Honkanen-Buzalski, T. (2010). Bovine Mastitis in Finland 2001-Prevalence, Distribution of Bacteria, and Antimicrobial Resistance. Journal of Dairy Science, 87(8), 2433-2441.

Podder, M. P., Rogers, L., Daley, P. K., Keefe, G. P., Whitney, H. G., \& Tahlan, K. (2014). Klebsiella species associated with bovine mastitis in Newfoundland. PLOS ONE, 9(9).

Saini, V., J. T. McClure, D. Léger, S. Dufour, A. G. Sheldon, D. T. Scholl, and H. W. Barkema. (2012). Antimicrobial use on Canadian dairy farms. J. Dairy Sci. 95, 1209-1221. 
Sampimon, O. C., Barkema, H. W., Berends, I. M. G. A., Sol, J., \& Lam, T. J. G. M. (2009). Prevalence and herd-level risk factors for intramammary infection with coagulase-negative staphylococci in Dutch dairy herds. Veterinary Microbiology, 134(2).

Sharma, R. M., \& Packer, R. A. (1970). Occurrence and ecologic features of Streptococcus uberis in the dairy cow. American Journal of Veterinary Research, 31(7), 1197-1202.

Speer, B. S., Shoemaker, N. B., \& Salyers2, A. A. (1992). Bacterial Resistance to Tetracycline: Mechanisms, Transfer, and Clinical Significance. Clinical Microbiology Reviews 5(4), 389-399.

Suleiman, T. S., Karimuribo, E. D., \& Mdegela, R. H. (2018). Prevalence of bovine subclinical mastitis and antibiotic susceptibility patterns of major mastitis pathogens isolated in Unguja island of Zanzibar, Tanzania. Tropical Animal Health and Production, 50(2), 259-266.

Sumon, S., Ehsan, M., \& Islam, M. (2017). Subclinical mastitis in dairy cows: somatic cell counts and associated bacteria in Mymensingh, Bangladesh. Journal of the Bangladesh Agricultural University, 15(2), 266-271.

Swartz, T. and Christina, S., P. (2016). Bacillus spp .: A Practical Summary for Controlling Mastitis. Virginia Tech. Virginia University, pp.1-2.

Tenhagen, B.-A, Kö, G., Wallmann, J., \& Heuwieser, W. (2006). Prevalence of Mastitis Pathogens and Their Resistance Against Antimicrobial Agents in Dairy Cows in Brandenburg, Germany. J. Dairy Sci, 89, 25422551.

Traversari, J., Van Den Borne, B. H. P., Dolder, C., Thomann, A., Perreten, V., \& Bodmer, M. (2019). Nonaureus staphylococci species in the teat canal and milk in four commercial swiss dairy herds. Frontiers in Veterinary Science, 6, 11-14.

Thrusfield, M.. (2007).Veterinary Epidemiology. Third edition. Oxford: Blackwell science Ltd; pp. 183-9.

Wang, W., Lin, X., Jiang, T., Peng, Z., Xu, J., Yi, L., Li, F., Fanning, S., \& Baloch, Z. (2018). Prevalence and Characterization of Staphylococcus aureus Cultured From Raw Milk Taken From Dairy Cows With Mastitis in Beijing, China. Frontiers in Microbiology, 9, 1123.

World Health Organization (WHO). 1997. Recommendations:The medical impact of the use of antimicrobials in food animals.WHO-Proceedings. WHO/EMC/ZOO/97.4, 1997. WHO, Geneva, Switzerland. pp. 11-16.

Zadoks, R. N., Middleton, J. R., McDougall, S., Katholm, J., \& Schukken, Y. H. (2011). Molecular Epidemiology of Mastitis Pathogens of Dairy Cattle and Comparative Relevance to Humans. Journal of Mammary Gland Biology and Neoplasia, 16(4), 357-372. 


\section{Figures}

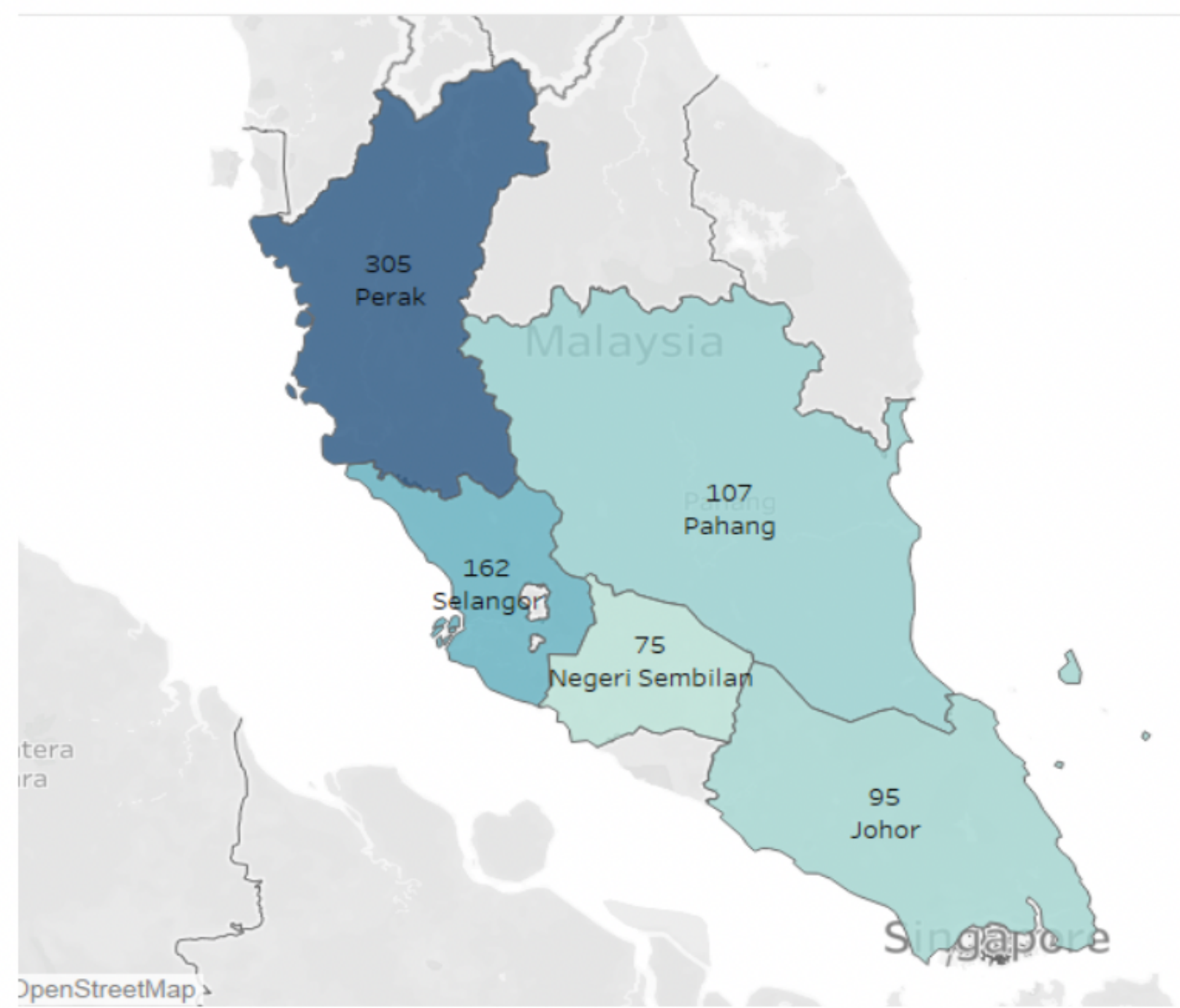

\section{Figure 1}

Latitude and Longitude generated Map showing the number of samples used in this study from each of the five Malaysian States (Created using Tableau Software). 


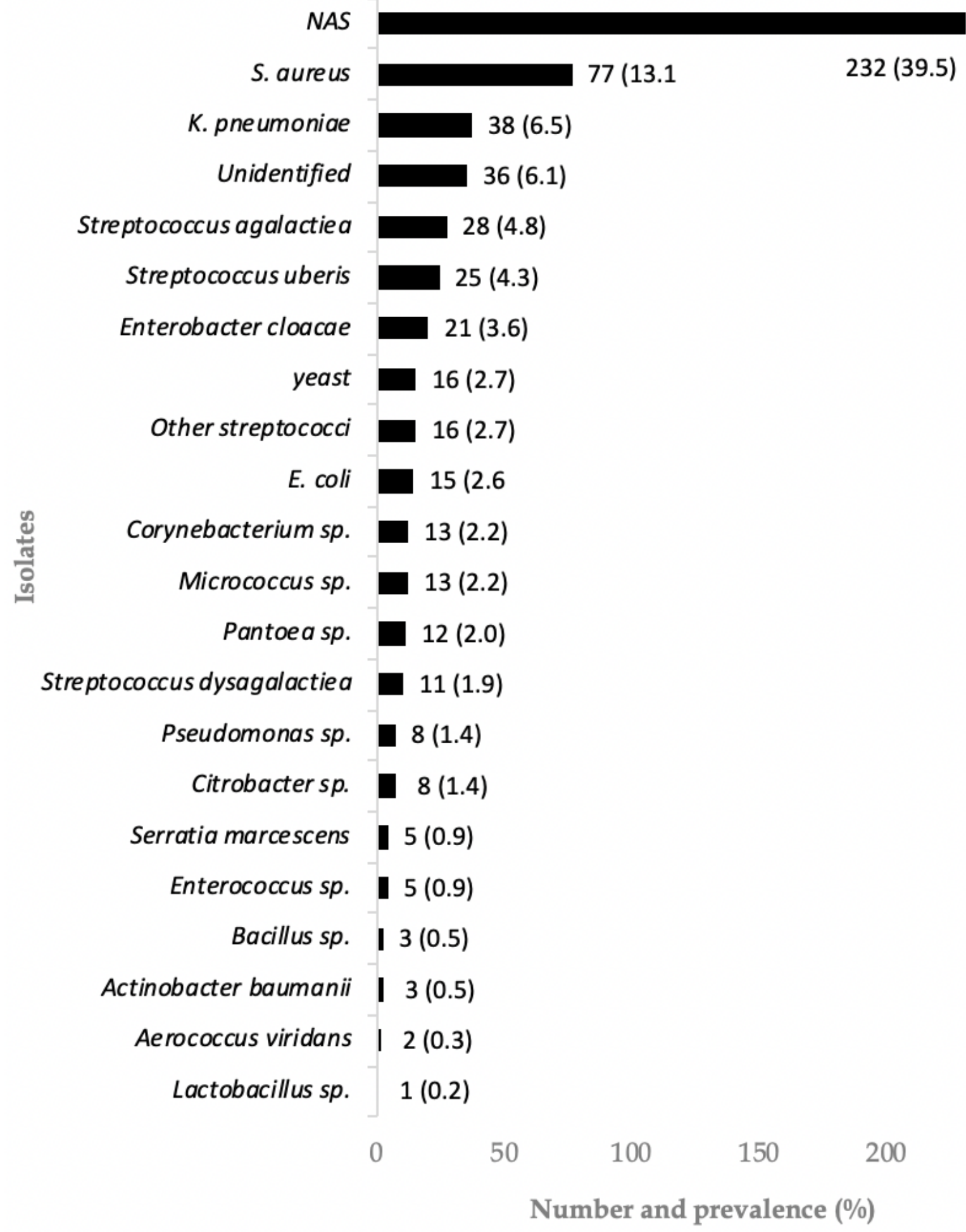

Figure 2

The distribution of bacterial pathogens associated with IMIs in selected states of Malaysia. *NAS comprises of S. intermedius, S. xylosus, S. scuiri, S. haemolyticus, S. lentus, S. chromogens, S. hominis, S. hyicus, S. epidermidis, S. lugdinensis, S. capitis, S. warneri, S. simulans, S. cohni, S. auricularis, S. saprophyticus and S. caprae. *Others includes Citrobacter spp, Pseudomonas spp, Serracia spp, Actinobacter spp and Providencia spp 


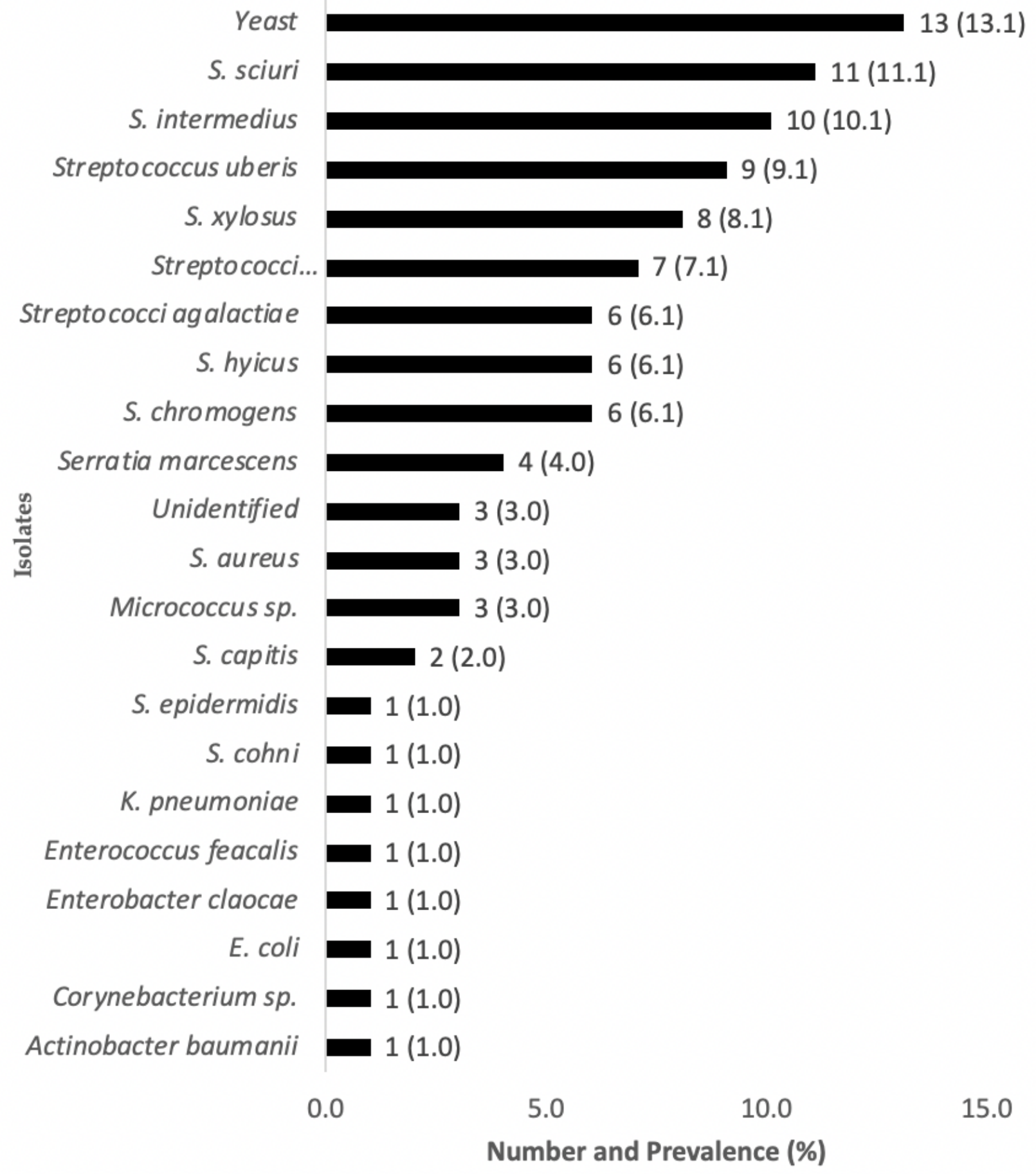

\section{Figure 3}

The distribution of bacterial pathogens associated with IMIs in Selangor 
S. haemolyticus

S. hominis

S. lugdunensis

Streptococcus uberis

S. aureus

S. intermedius

Unidentified

S. epidermidis

Enterbacter cloacae

S. chromogens

S. warneri
S. auricularis
Enterococcus sp.
Corynebacterium sp.

Bacillus sp.

S. capitis

S. sciuri

S. simulans

S. xylosus

S. hyicus

Aerococcus viridans

Lactobacillus sp.

Pantoea sp.
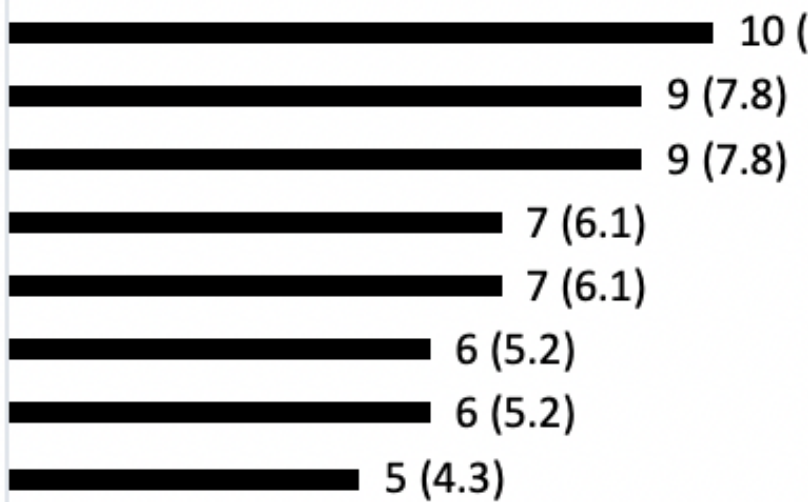

(8.7)

$5(4.3)$

4 (3.5)

3 (2.6)

3 (2.6)

3 (2.6)

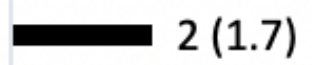

2 (1.7)

2 (1.7)

2 (1.7)

- 1 (0.9)

- 1 (0.9)

- 1 (0.9)

- 1 (0.9)

0

2

4

6

$8 \quad 10$

12

14

Number and Prevalence (\%)

Figure 4

The distribution of bacterial pathogens associated with IMIs in Negeri Sembilan 


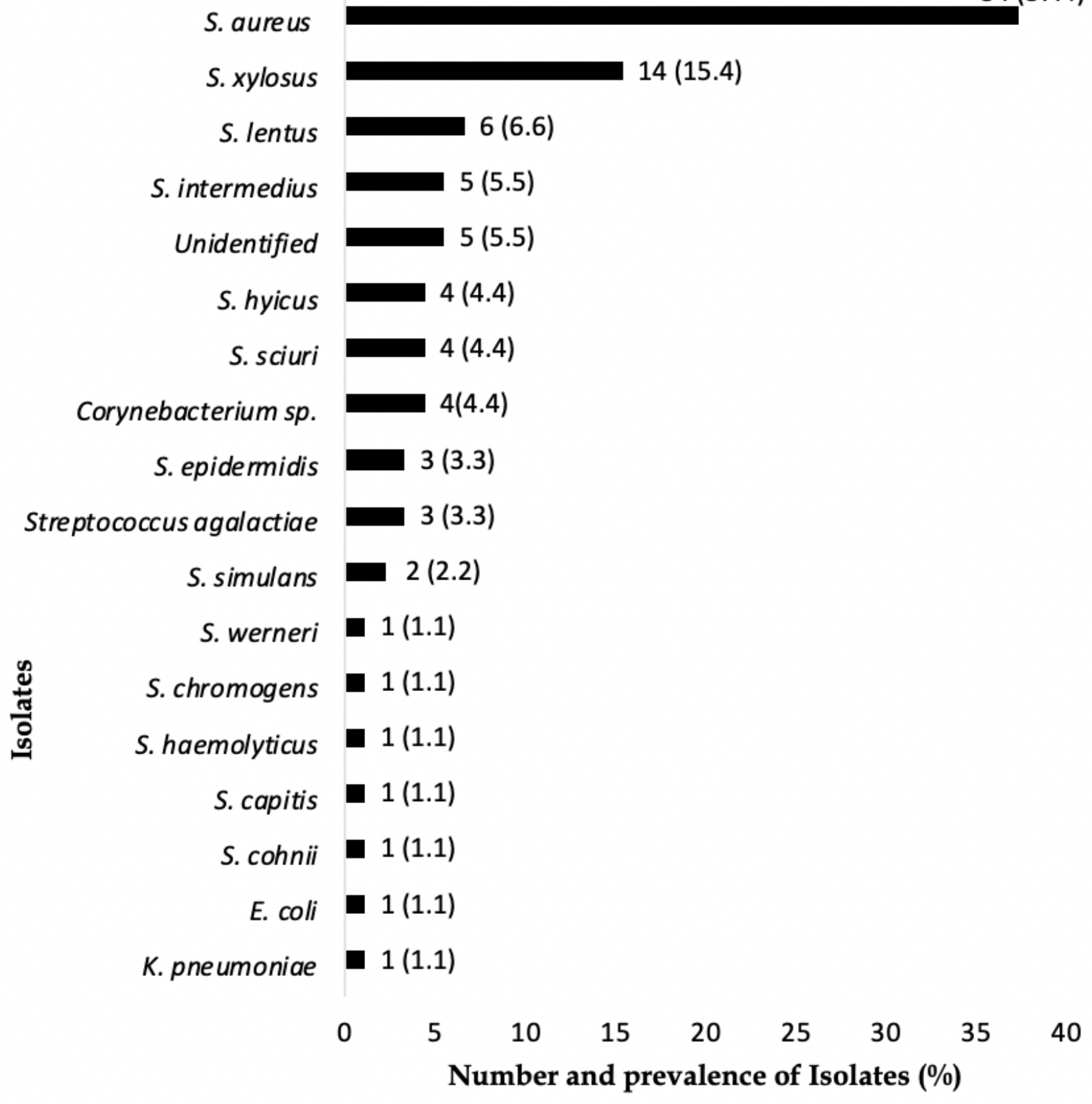

Figure 5

The distribution of bacterial pathogens associated with IMIs in from Johor 


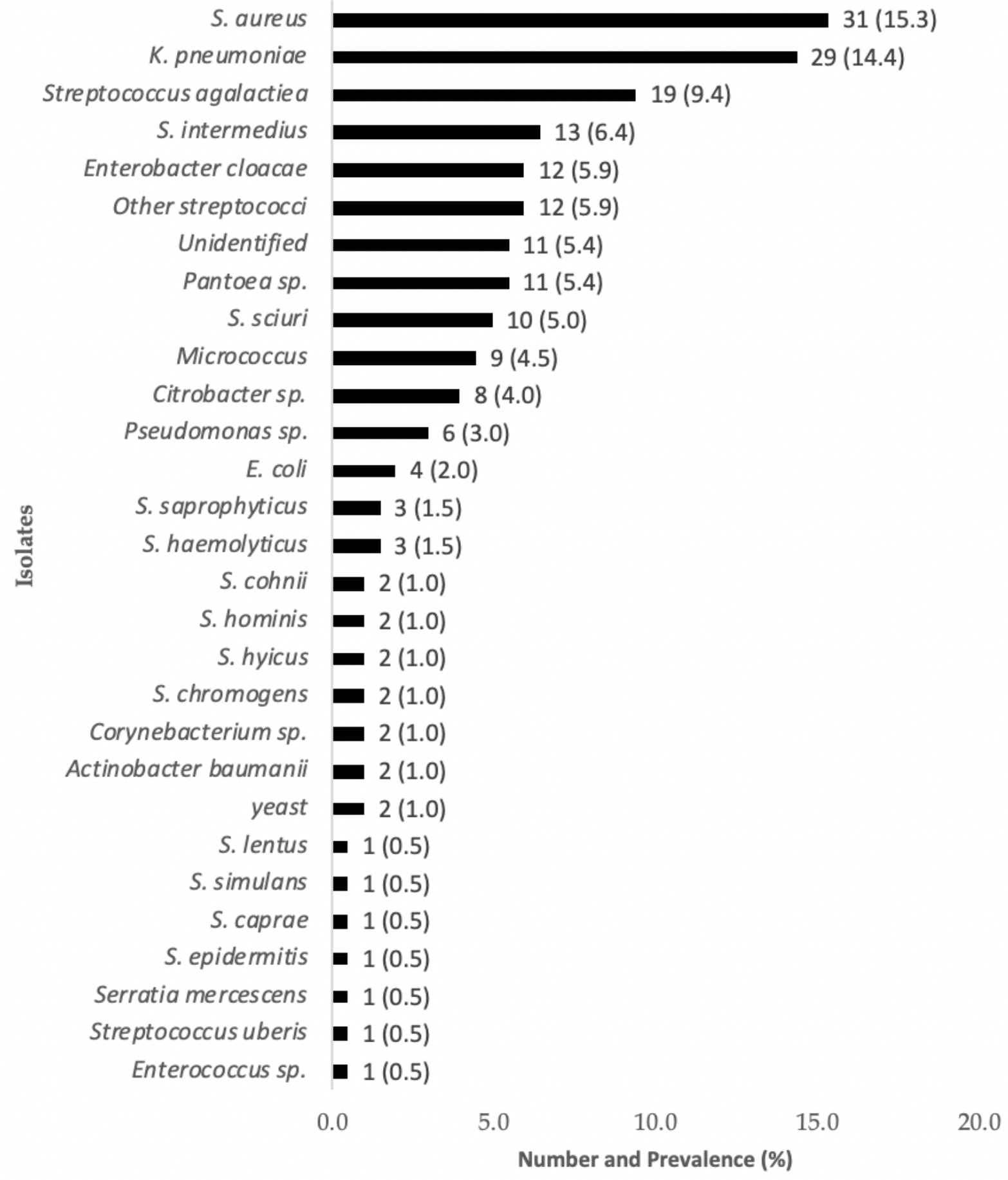

\section{Figure 6}

The distribution of bacterial pathogens associated with IMls in Perak 


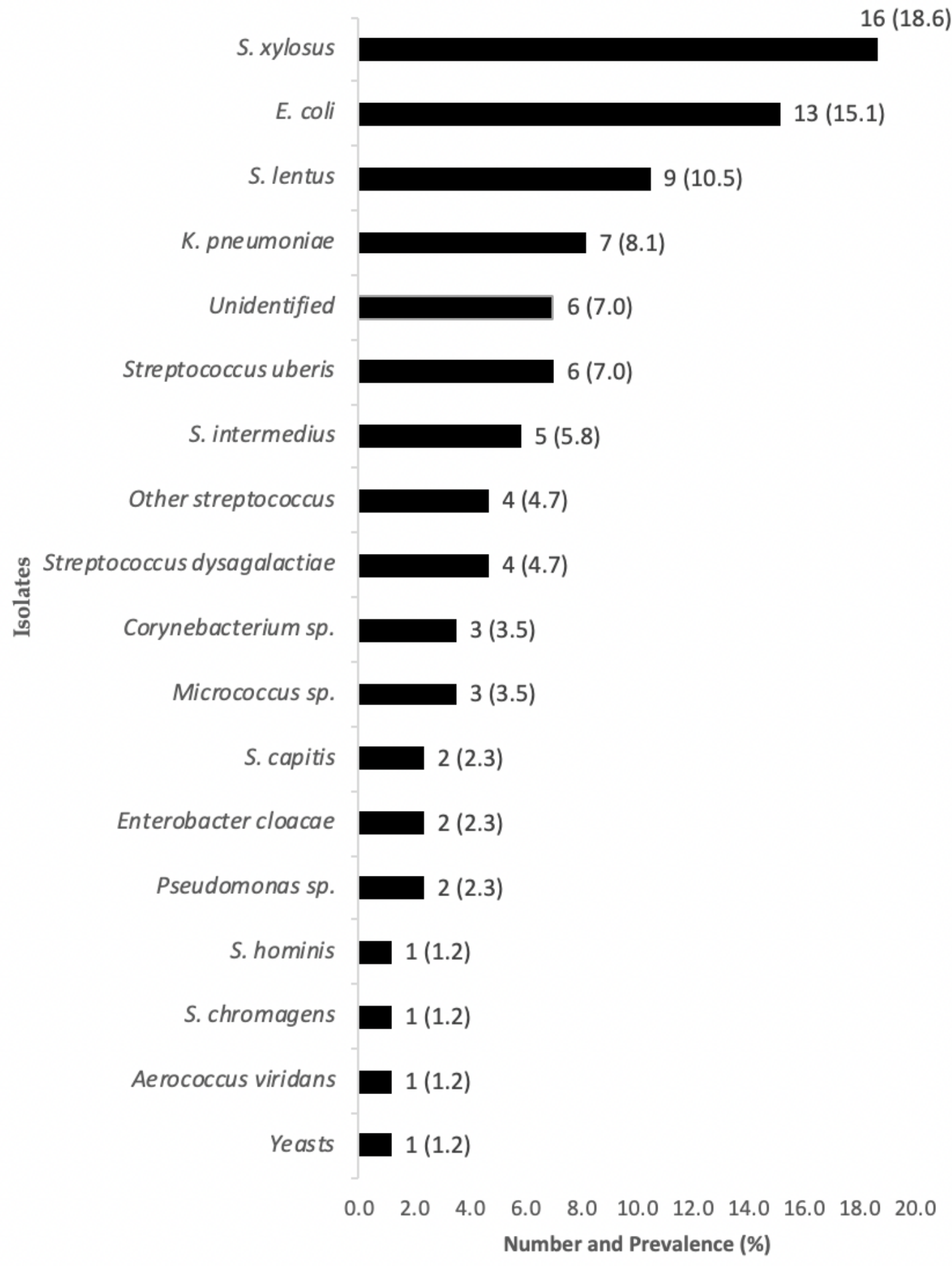

\section{Figure 7}

The distribution of bacterial pathogens associated with IMls in Pahang 


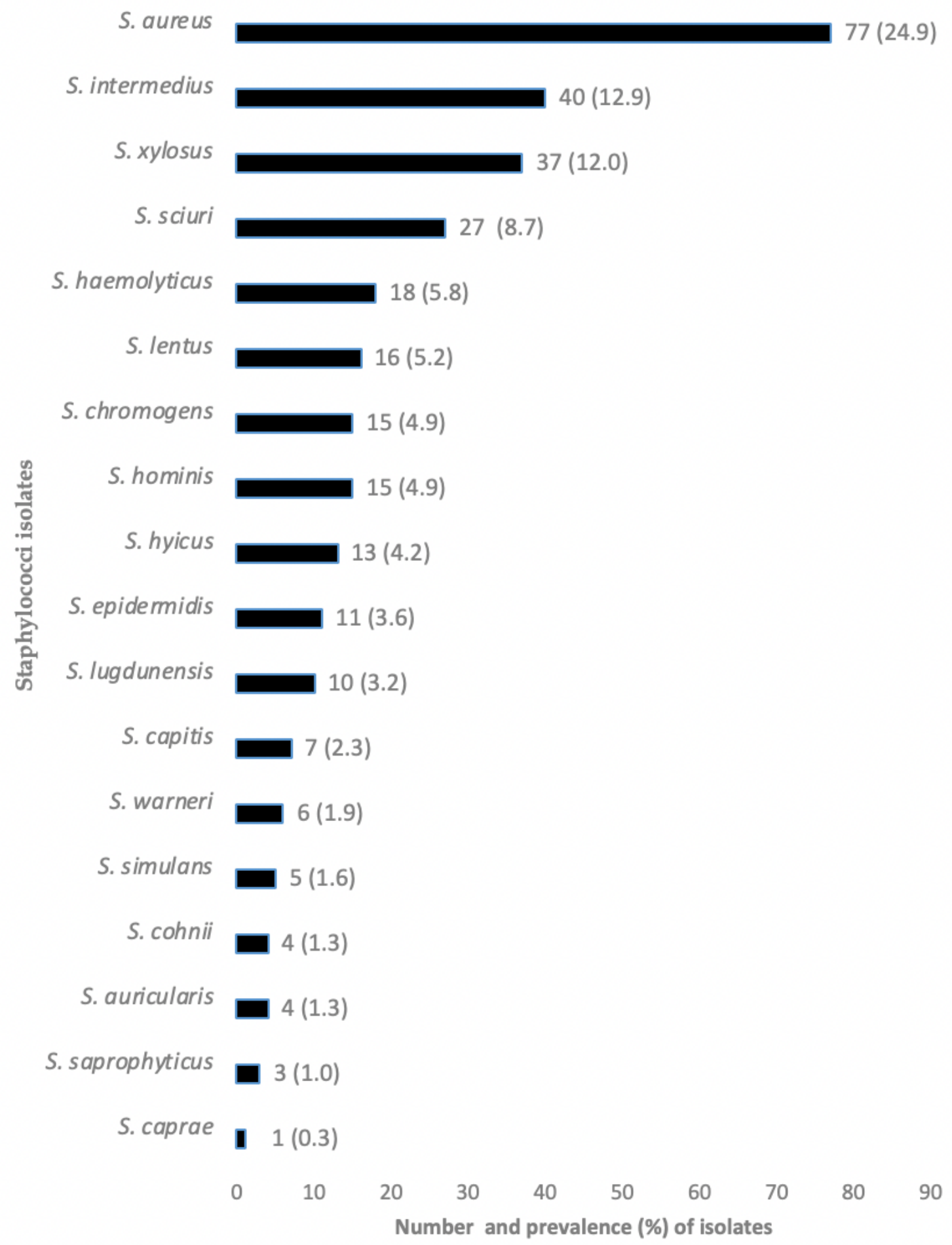

\section{Figure 8}

Composition and prevalence of non-aureus staphylococci (NAS) in comparison with S. aureus isolates associated IMIs in selected states of Malaysia. 